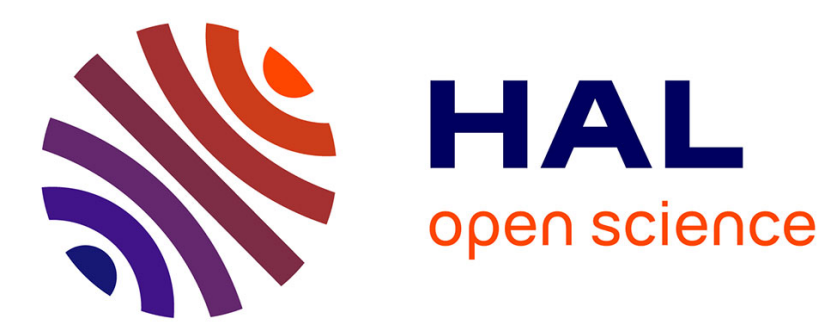

\title{
A Gamified HMI as a Response for Implementing a Smart-Sustainable University Campus
}

Juana Isabel Méndez, Pedro Ponce, Therese Peffer, Alan Meier, Arturo Molina

\section{To cite this version:}

Juana Isabel Méndez, Pedro Ponce, Therese Peffer, Alan Meier, Arturo Molina. A Gamified HMI as a Response for Implementing a Smart-Sustainable University Campus. 22nd Working Conference on Virtual Enterprises (PRO-VE 2021), Nov 2021, Saint-Etienne, France. pp.683-691, 10.1007/978-3030-85969-5_64. emse-03349710

\section{HAL Id: emse-03349710 https://hal-emse.ccsd.cnrs.fr/emse-03349710}

Submitted on 25 Nov 2021

HAL is a multi-disciplinary open access archive for the deposit and dissemination of scientific research documents, whether they are published or not. The documents may come from teaching and research institutions in France or abroad, or from public or private research centers.
L'archive ouverte pluridisciplinaire HAL, est destinée au dépôt et à la diffusion de documents scientifiques de niveau recherche, publiés ou non, émanant des établissements d'enseignement et de recherche français ou étrangers, des laboratoires publics ou privés. 
Méndez J.I., Ponce P., Peffer T., Meier A., Molina A. (2021) A Gamified HMI as a Response for Implementing a Smart-Sustainable University Campus. In: Camarinha-Matos L.M., Boucher X., Afsarmanesh H. (eds) Smart and Sustainable Collaborative Networks 4.0. PRO-VE 2021. IFIP Advances in Information and Communication Technology, vol 629. Springer, Cham. https://doi.org/10.1007/978-3-030-85969-5_64

\title{
A Gamified HMI as a Response for Implementing a Smart-Sustainable University Campus
}

\author{
Juana Isabel Méndez ${ }^{1[0000-0001-5337-2527]}$, Pedro Ponce ${ }^{10000-0001-7035-5286]}$, \\ Therese Peffer ${ }^{3[0000-0001-5569-7448]}$, Alan Meier ${ }^{4[0000-0002-1260-2151]}$, and \\ Arturo Molina 1[0000-0001-5461-2879] \\ ${ }^{1}$ School of Engineering and Sciences, Tecnologico de Monterrey, México City, México \\ A01165549@itesm.mx, pedro.poncedtec.mx, armolina@tec.mx \\ ${ }^{3}$ Institute for Energy and Environment, University of California, Berkeley, CA. 94720, USA \\ tpefferaberkeley.edu \\ ${ }^{4}$ Energy and Efficiency Institute, University of California, Davis, CA. 95616, USA \\ akmeier@ucdavis.edu
}

\begin{abstract}
Universities need to explore drastic changes regarding their facilities to be more inclusive and sustainable. Those changes must move forward to a Smart university campus. A Smart University Campus involves Smart City's concept because different socio-cultural aspects in the community and services like health care, public safety, mobility, education, transportation, and energy are integrated into the Campus. For instance, $25 \%$ of the total electric consumption comes from the cooling in an educational facility. Besides, energy awareness campaigns reach $5 \%$ to $15 \%$ energy cost savings. Nevertheless, the end-users do not engage in those applications due to multiple platform requirements and the generalization of a conventional user; thus, energy awareness is not reached. Knowing the type of user enhances gamification strategies that engage them in energy reduction activities without being obtrusive. Through collaborative networks, the university members socially interact with others, strengths their relationships, and improve their skills toward saving energy. Hence, this paper proposes a case study located at the Tecnologico de Monterrey, Mexico City Campus and analyzes six different scenarios to understand the energy impacts of using different cooling values on thermostats during classes. Dividing these services into a three-level gamified interface: Smart building, Smart Community, and Smart Campus to promote energy awareness to reduce electrical consumption. Besides, if the reference temperature is set correctly, a terminal comfort is achieved, the students and professors could increment their work performance. This gamified interface runs a feed-forward Artificial Neural Network (ANN) as a decision-making system that supports the proposed structure.
\end{abstract}

Keywords: Smart City, Smart Campus, Gamification, Energy Awareness, personality traits. 


\section{Introduction}

The electricity end-user sector is often divided into the residential, commercial, and public, transport, industrial, and agricultural sectors. According to the last record in SENER, in 2019, the Mexican electricity consumption were about 284 billion $\mathrm{kWh}$, with $22.7 \%, 12.3 \%, 0.4 \%, 60 \%$, and $4.6 \%$ respectively [16]. Therefore, it is a challenge to reduce electrical consumption without being invasive or losing quality of life. Moreover, citizens represent the linkage, the main actor, and the sensor to the city, as they actively interact with it. Consequently, users' interaction plays a primary role in understanding and knowing the city to reduce electrical consumption. However, teaching them how to reduce electrical consumption represents a challenge as sometimes they have other interests rather than reducing their consumption. In that regard, the education offered, for instance, in a university, seems the ideal place, to begin with, the interaction between the user and the city to become energy awareness.

Innovative education considers an interactive, collaborative, and visual model to continually engage students and allow teachers to adapt to new students' skills [7]. Therefore, it requires design, development, implementation, and active use of innovative systems, technologies, teaching, and learning strategies [19]. Besides, smart education is a crucial element in smart city development [9]. In that sense, universities as Tecnologico de Monterrey support smart education through novel learning methods, including open innovation laboratories for knowledge transference [12], for instance, for electrical energy education [15]. $25 \%$ of the total electric consumption comes from cooling in an educational facility [7]. Energy awareness campaigns promote electrical energy reduction, and it can reach from $5 \%$ to $15 \%$ of energy cost savings with scarce to no investment $[4,13,18]$. Therefore, incorporating gamification techniques to target energy reduction as a goal is not as complicated as it may seem. For example, providing an HMI that monitors the cooling setpoint in classrooms can save energy. According to [3], by increasing $1{ }^{\circ} \mathrm{C}$ the thermostat during summer periods, $6 \%$ of the electricity consumed can be saved. In addition, implementing tailored gamification strategies in Human Machine-Interfaces (HMI) can engage end-users to reduce energy consumption by considering their personality traits [14].

Moreover, collaborative networks consider socio-cultural people, services, facilities, urban planning, or governance systems, for instance, in smart cities $[2,9,20]$. Thus, this paper conceptualizes a Smart Campus as a Smart City. The Tecnologico de Monterrey, Mexico City Campus was employed as a case study.

\section{$2 \quad$ Methodology}

The smart building model considered six cases for a typical classroom during cooling periods to measure the impact of increasing the cooling setpoint starting from $22^{\circ} \mathrm{C}$ and increase a $0.5^{\circ} \mathrm{C}$ for each case, ending with $24.5^{\circ} \mathrm{C}$ for the sixth case. Each classroom considered a cooling setback of $27^{\circ} \mathrm{C}, 20^{\circ} \mathrm{C}$ for the heating setpoint, and $12.8^{\circ} \mathrm{C}$ for the heating setback. This proposal aims to sensibilize the students the importance of well managing the cooling setpoint. Other considerations for the energy model included 
Mexico City's weather file, the construction materials, the classroom schedule and loads, and the setpoint and setback for cooling and heating. As a result, the energy model gave the total cooling $\mathrm{kWh}$ per case. Ladybug Tools for Grasshopper were used for the energy simulation [11]. The ANN model considered for the input values the month, day, hour, and setpoint to predict the $\mathrm{kWh}$ usage for that specific conditions. Besides, this proposal considered five personality traits obtained in a worldwide database by [1]. Then, it was related to the eight-core drives proposed by Chou [5] and updated with energy game elements by Ponce et al. [14]. The database was filtered only to consider the Mexican responses. Thus, the ANN model used as input values the gender, age, and personality trait to predict which core drive should consider the HMI proposal. Hence, a two-layer feed-forward ANN decision-making system was modeled using the Neural Network Pattern Recognition from MATLAB. Simulink software was used to implement a dashboard prototype that analyzed the results from the ANN.

\section{Proposed Framework}

Fig.1 displays the proposed framework. This framework proposes three steps per integration: Smart building integration, smart community integration, and smart campus integration. In addition, within each integration, three stages are proposed: knowledge base, decision system, and evaluation stage.

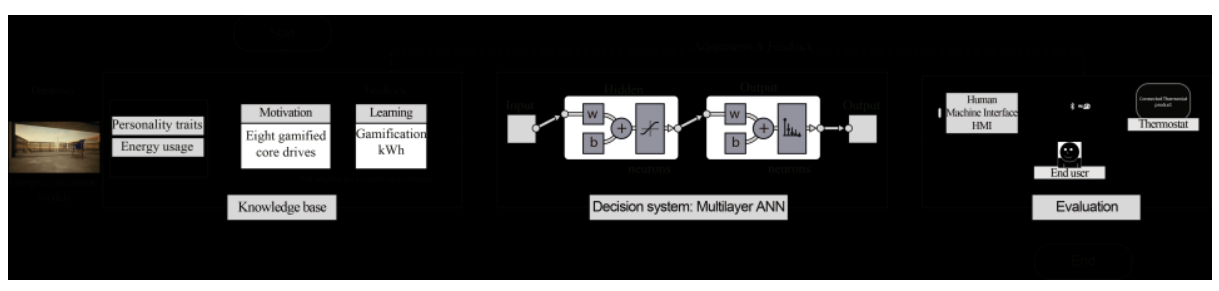

Fig. 1. Proposed framework.

\subsection{Knowledge Base Stage}

Six cases were analyzed using the same classroom in terms of location, orientation, construction material, schedules, loads, heating setpoint/setback, and cooling setback. To recreate the interaction in a building and analyze the different changes based on the setpoint decisions, Fig. 2. depicts the cooling setpoint considered for each case. Besides, the legend shows the total $\mathrm{kWh}$ consumption by case and obtained from the energetic model. Table 1 presents the eight-core gamification drives, their associated personality traits, and game elements considered in this paper $[5,14]$. The database used to relate the personality traits with the core drives was obtained from [1]. This database had the answers per country, gender, age, and personality traits; thus, the observations were filtered to select Mexico. Openness personalities are open to learning new things. Conscientious personalities are rule followers, competitive, and self-discipline. Extra- 
664 J. I. Méndez et al.

version personalities are optimistic, assertive, and appreciate social interactions. Agreeable personalities are sympathetic, tolerant, and cooperative. Neuroticism personalities are impulsive, stressful, and bad-tempered [10, 14].

\subsection{ANN Decision System Stage}

A two-layer feed-forward ANN decision-making system was modeled to predict the $\mathrm{kWh}$ consumption depending on the cooling setpoint proposed in Fig. 2. In addition, the gamified core drive was required for the interface design depending on age and gender, and personality traits of the end-user proposed in Table 2. Based on the total $\mathrm{kWh}$ consumption by case, the setpoint/setback from the 17105 observations was used to feed the ANN; the input values for the $\mathrm{kWh}$ prediction were the month, day, hour, and setpoint; whereas the output value was the kWh consumption by observation. For the case of the type of gamified proposal, 700 observations were used. The input values were the gender, age, and personality traits; the output values were each core drive. For the particular case of Mexico, all the respondents had similarities in the core drives one, three, four, five, and seven. However, core drives three, six, and eight had diverse answers, meaning that some respondents required core drive three, while others core drive six or eight. The ANNs used a two-layer feed-forward network with 100 neurons in its hidden layer and used a hyperbolic tangent sigmoid transfer function. Finally, the ANN was exported into Simulink to design a dashboard prototype.

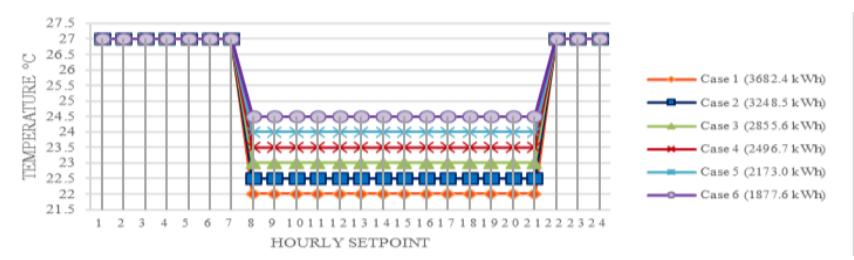

Fig. 2. Cooling setpoint considered for each case and its total $\mathrm{kWh}$ consumption.

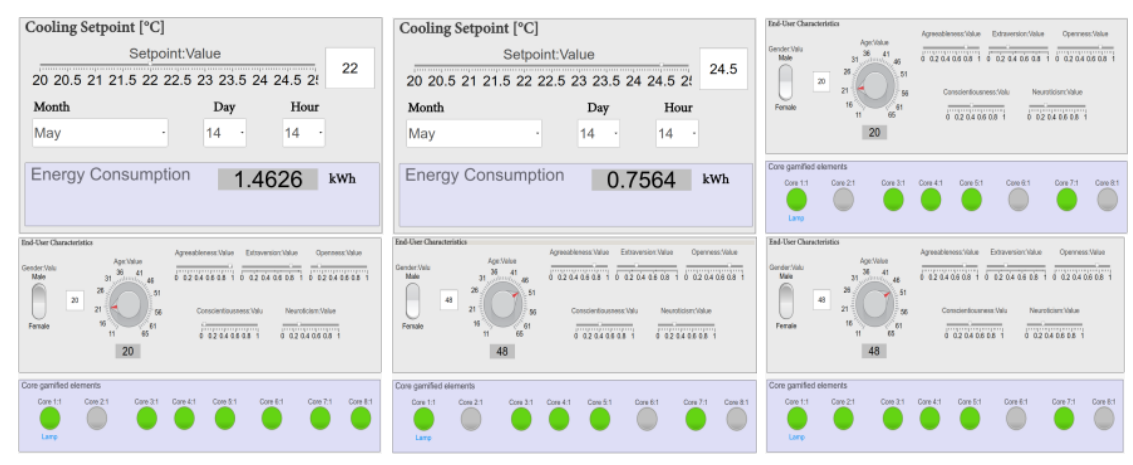

Fig. 3. Dashboard prototype. 


\subsection{Evaluation Stage}

Fig 3. displays a dashboard prototype programmed using Simulink/MATLAB that the students and professors can access. They can select the cooling setpoint, month, day, and hour to know the energy consumption at this specific time. Besides, depending on the gender, age, and personality traits, the core drive is activated with a green light to determine the gamification elements needed to propose the HMI interface.

Table 1. Eight core drives, their associated personality traits, and gamification elements.

\begin{tabular}{|c|c|c|}
\hline Core drive & Personality trait & Gamification element \\
\hline $\begin{array}{l}\text { 1. Epic meaning and call- } \\
\text { ing }\end{array}$ & $\begin{array}{l}\text { Extraversion, Agreeable- } \\
\text { ness, Conscientiousness, } \\
\text { Openness }\end{array}$ & $\begin{array}{l}\text { Narrative, elitism, beginners lick, } \\
\text { higher meaning, co-creator. }\end{array}$ \\
\hline $\begin{array}{l}\text { 2. Development and Ac- } \\
\text { complishment }\end{array}$ & Conscientiousness & $\begin{array}{l}\text { Offers, coupons, bill discounts, chal- } \\
\text { lenges, levels, badges, points, leader- } \\
\text { board, progress bar. }\end{array}$ \\
\hline $\begin{array}{l}\text { 3. Empowerment of Crea- } \\
\text { tivity and Feedback }\end{array}$ & $\begin{array}{l}\text { Extraversion, Neuroticism, } \\
\text { Openness }\end{array}$ & $\begin{array}{l}\text { Notifications, messages, tips, real- } \\
\text { time control. }\end{array}$ \\
\hline $\begin{array}{l}\text { 4. Ownership and Posses- } \\
\text { sion }\end{array}$ & $\begin{array}{l}\text { Extraversion, Agreeable- } \\
\text { ness, Neuroticism, Open- } \\
\text { ness }\end{array}$ & $\begin{array}{l}\text { Dashboard, statistics, collection set, } \\
\text { learning curve, monitoring, degree } \\
\text { of control, recruitment. }\end{array}$ \\
\hline $\begin{array}{l}\text { 5. Social Influence and } \\
\text { Relatedness }\end{array}$ & $\begin{array}{l}\text { Extraversion, Agreeable- } \\
\text { ness, Conscientiousness, } \\
\text { Openness, Neuroticism }\end{array}$ & $\begin{array}{l}\text { Energy community, collaboration, } \\
\text { control over peers, social compari- } \\
\text { son, competition, mentorship. }\end{array}$ \\
\hline 6. Scarcity and patience & Neuroticism & Prize pacing, appointment dynamics. \\
\hline $\begin{array}{l}\text { 7. Unpredictability and } \\
\text { Curiosity }\end{array}$ & $\begin{array}{l}\text { Extraversion, Neuroticism, } \\
\text { Openness }\end{array}$ & $\begin{array}{l}\text { Mini quests, visual storytelling, roll- } \\
\text { ing rewards, random rewards. }\end{array}$ \\
\hline 8. Loss and avoidance & Neuroticism & $\begin{array}{l}\text { Progress loss, evanescence oppor- } \\
\text { tunity. }\end{array}$ \\
\hline
\end{tabular}

\section{$4 \quad$ Results}

Fig 4 shows a three-level HMI considering a setpoint of $22^{\circ} \mathrm{C}$ during cooling periods. Thus, gamified core drives one, two, four, six, and eight are displayed on an online set of stimuli based on rewards, challenges, and a dashboard to display how much electricity is wasting the building. Fig. 4 (a) displays the interface for the classroom considering the professor's perspective interface. Therefore, following the evaluation subsection, this type of user is a 48 years old male with higher agreeableness and openness personality traits and lower extraversion, conscientiousness, and neuroticism personality traits. In addition, this interface requires taking into account core drives one, three, four, five, and seven; thus, it emphasizes the community and co0llaborative networks, displaying messages of the benefits of increasing the thermostat setpoints and gives some tips on improving energy savings.

Fig 4 (b) shows the interfaces from the students' perspective. This student is a 20 years old female with higher agreeableness and extraversion personality traits and lower openness, conscientiousness, and neuroticism personality traits. In addition, this 
interface requires the six and eight-core drive; thus, the interface displays specific messages that suggest progress loss, evanescence opportunities, and prize pacing as a motivation for this user type to accept and reduce energy consumption. The teacher proposes the setpoint increase, and the student receives the option to accept or decline the proposal. Fig. 4 (c) displays the smart community interface as a collaborative network where members can interact with others and visualize which building wins to promote competitions and challenges to motivate each team to reduce energy. Finally, fig. 4 (d) displays the Smart Campus services and displays the winning community.
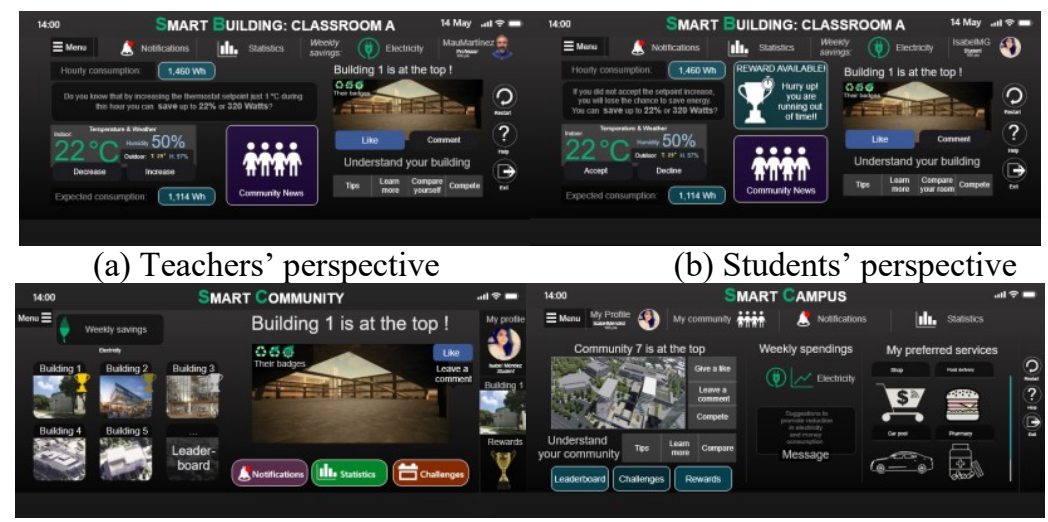

(a) Smart community HMI

(b) Smart Campus HMI

Fig. 4. Three-level interface proposal for the Smart Campus: (a) Smart Building from the teacher's perspective, (b) student's perspective, (c) Smart Community, and (d) Smart Campus.

\section{Discussion}

The literature shows gamification approaches within a smart city context, including using multiple platforms or applications to promote energy consciousness. However, these approaches do not consider end-users types and often consider typical users or generic users. Thus, users do not engage and use the interfaces because there are complex to use at the same time these multiple applications.

As a university involves different types of collaborative networks, users with different socio-cultural aspects represent a challenge in reducing energy; however, providing a gamification structure could allow all the members to reduce energy reduction strategies. The smart community structure is grouped into faculties by educational level (high school and university), administrative and business areas, cultural buildings, and research facilities. Besides, the management area has the credentials to determine which type of information is displayed to other community members and propose any change and share their tips on saving more energy or improving the quality of life at Campus. An example is sending tips or messages to the end-users and suggesting that increasing the thermostat's setpoint during cooling periods can help the Campus reduce electrical consumption. Besides, all the members can share their tips for saving energy or even 
build an energy community. Therefore, an achievable goal is to reduce electrical consumption by accepting changes on the setpoint that does not affect the community.

As the Mexican responses coincided with epic meaning and calling, empowerment of creativity and feedback, ownership and possession, social influence and relatedness, unpredictability, and curiosity, any of these drives can be proposed for the HMI. Then, specific types of Mexicans had other personality traits that conveyed the development and accomplishment, scarcity and patience, and loss and avoidance. For instance, the interface can consider using progress loss or appointment dynamics to engage the user in reducing energy consumption. The gamification strategy integrates all the community involved in each building through social sharing activities or group challenges, so the community is motivated to reduce energy consumption. Besides, through the gamified HMIs and big data analytics, energy behavior patterns can be identified, tracked, and forecasted energy behavior patterns to promote energy reductions $[8,17]$. However, behavioral adjustment, physiological adaption, and psychological dimensions of thermal adaptation intervene during these group decisions [6].

\section{Conclusion}

The six cases considered the occupied periods in a classroom from 8 am to $9 \mathrm{pm}$; therefore, students and academics can collaborate in bringing new ideas upon saving electrical energy during cooling periods. A significant determinant to reduce energy consumption during summer periods is the collaboration between students and professors. Collaboration promotes social interaction, strengthens relationships, and improves skills. For instance, during cooling periods, the thermostat setpoints in classrooms ranged from $22^{\circ} \mathrm{C}$ to $24.5^{\circ} \mathrm{C}$. There was a $50 \%$ of savings from adjusting the thermostat setpoint from $22^{\circ} \mathrm{C}$ to $24.5^{\circ} \mathrm{C}$. Therefore, the cooling setpoint in a classroom should be at least $22{ }^{\circ} \mathrm{C}$ or above. This paper proposes implementing a gamification structure in three levels through a two-layer feed-forward ANN decision system to promote energy awareness in university students. Thus, the energy model was simulated to propose gamification strategies based on the cooling setpoints. The proposal relies on using a single HMI to access three levels of the smart Campus, access the classroom and building, and the community and the Campus. This proposal aims to profile and know each building's energy patterns and the interaction of the buildings in the community and the whole Campus to deploy an application that improves the quality of life.

Acknowledgments This research project is supported by Tecnologico de Monterrey and CITRIS under the collaboration ITESM-CITRIS Smart thermostat, deep learning, and gamification project (https://citris-uc.org/2019-itesm-seed-funding/).

\section{References}

1. automoto (2021) automoto/big-five-data

2. Ben Yahia N, Eljaoued W, Bellamine Ben Saoud N, Colomo-Palacios R (2021) Towards sustainable collaborative networks for smart cities co-governance. International Journal of Information Management 56:102037. doi: 10.1016/j.ijinfomgt.2019.11.005 
668 J. I. Méndez et al.

3. Bureau of Energy Efficiency (2018) Energy Conservation in Building Space Cooling through recommended optimum temperature setting

4. Capehart BL, Kennedy WJ, Turner WC (2012) Guide to Energy Management. Fairmont Press, Lilburn, GA

5. Chou Y (2015) Actionable Gamification Beyond Points, Badges, and Leaderboards. CreateSpace Independent Publishing Platform

6. de Dear RJ, Brager GS (1998) Developing an Adaptive Model of Thermal Comfort and Preference. UC Berkeley: Center for the Built Environment

7. Energy Star (2006) 10. Facility Type: K-12 Schools. In: Energy Star. https://www.energystar.gov/sites/default/files/buildings/tools/EPA_BUM_CH10_Schools.pdf

8. Giest S (2017) Big data analytics for mitigating carbon emissions in smart cities: opportunities and challenges. European Planning Studies 25:941-957. doi: $10.1080 / 09654313.2017 .1294149$

9. Glasco J (2019) Smart Education for Smart Cities: Visual, Collaborative \& Interactive. https://hub.beesmart.city/en/solutions/smart-people/smart-education/viewsonic-smart-education-for-smart-cities. Accessed 28 Nov 2020

10. John OP, Srivastava S (1999) The Big Five Trait taxonomy: History, measurement, and theoretical perspectives. In: Handbook of personality: Theory and research, 2nd ed. Guilford Press, New York, NY, US, pp 102-138

11. Ladybug Tools Ladybug Tools | Home Page. https://www.ladybug.tools/. Accessed 2 May 2021

12. Miranda J, Chavarría-Barrientos D, Ramírez-Cadena M, Macías ME, Ponce P, Noguez J, Pérez-Rodríguez R, Wright PK, Molina A (2017) Open Innovation Laboratory for Rapid Realization of Sensing, Smart and Sustainable Products (S3 Products) for Higher Education. $11: 7$

13. Paone A, Bacher J-P (2018) The Impact of Building Occupant Behavior on Energy Efficiency and Methods to Influence It: A Review of the State of the Art. Energies 11:953. doi: 10.3390/en11040953

14. Ponce P, Meier A, Mendez J, Peffer T, Molina A, Mata O (2020) Tailored gamification and serious game framework based on fuzzy logic for saving energy in smart thermostats. Journal of Cleaner Production 121167. doi: 10.1016/j.jclepro.2020.121167

15. Ponce P, Polasko K, Molina A (2019) Open innovation laboratory in electrical energy education based on the knowledge economy. International Journal of Electrical Engineering \& Education 002072091982971. doi: 10.1177/0020720919829711

16. Secretaría de Energía (2020) SENER | Sistema de Información Energética | Electricidad. In: Sistema de Información Energética. https://sie.energia.gob.mx/bdiController.do?action=cuadro\&subAction=applyOptions. Accessed 15 Jun 2021

17. Tamym L, Benyoucef L, Nait Sidi Moh A, El Ouadghiri MD (2021) A big data based architecture for collaborative networks: Supply chains mixed-network. Computer Communications 175:102-111. doi: 10.1016/j.comcom.2021.05.008

18. Turner WC, Doty S (2013) Energy Management Handbook. Fairmont Press, Lilburn, GA

19. Uskov VL, Howlett RJ, Jain LC (2020) Smart Education and e-Learning 2020. Springer Singapore, Singapore

20. Wang S, Wang J, Wei C, Wang X, Fan F (2021) Collaborative innovation efficiency: From within cities to between cities-Empirical analysis based on innovative cities in China. Growth and Change grow.12504. doi: 10.1111/grow.12504 